\title{
Major regulators of microRNAs biogenesis Dicer and Drosha are down-regulated in endometrial cancer
}

\author{
Anna Torres • Kamil Torres • Tomasz Paszkowski • \\ Barbara Jodłowska-Jędrych • Tomasz Radomański • \\ Andrzej Książek • Ryszard Maciejewski
}

Received: 28 February 2011 /Accepted: 13 April 2011 /Published online: 11 May 2011

(C) The Author(s) 2011. This article is published with open access at Springerlink.com

\begin{abstract}
Alterations in microRNAs expression have been proposed to play role in endometrial cancer pathogenesis. Dicer and Drosha are main regulators of microRNA biogenesis and deregulation of their expression has been indicated as a possible cause of microRNAs alterations observed in various cancers. The objective of this study was to investigate Dicer and Drosha genes expression in endometrial cancer and to analyze the impact of clinicopathological characteristics on their expression. Fresh tissue
\end{abstract}

Electronic supplementary material The online version of this article (doi:10.1007/s13277-011-0179-0) contains supplementary material, which is available to authorized users.

A. Torres $\cdot$ K. Torres $\cdot$ R. Maciejewski

Laboratory of Biostructure, Department of Human Anatomy,

Medical University of Lublin,

ul. Jaczewskiego 4,

20-094 Lublin, Poland

A. Torres $\cdot$ T. Paszkowski $\cdot$ T. Radomański

III Department of Gynecology, Medical University of Lublin, ul. Jaczewskiego 8,

20-094 Lublin, Poland

K. Torres

General and Oncologic Surgery Department, Lublin County

Specialist Hospital,

ul. Kraśnicka 100,

Lublin, Poland

B. Jodłowska-Jędrych

Department of Histology and Embryology with Experimental

Cytology Unit, Medical University of Lublin,

ul. Radziwiłłowska 11,

20-080 Lublin, Poland

\section{A. Książek}

Department of Nephrology, Medical University of Lublin,

ul. Jaczewskiego 8,

20-094 Lublin, Poland samples were collected from 44 patients (26 endometroid endometrial carcinoma and 18 controls). Clinical and pathological data were acquired from medical documentation. Dicer and Drosha genes expressions were assessed by qRT-PCR using validated reference genes. Dicer and Drosha expression levels were significantly lower in endometrial cancer samples comparing to controls. Dicer was down-regulated by the factor of $1.54(p=0.009)$ and Drosha gene mean expression value was 1.4 times lower in

R. Maciejewski

II Department of Surgery, Medical University of Lublin,

ul. Staszica 16,

20-081 Lublin, Poland

R. Maciejewski

Medical Emergency Department, UITM in Rzeszów,

ul. Sucharskiego 2,

35-225 Rzeszów, Poland

A. Torres $(\bowtie)$

Katedra i Zakład Anatomii Prawidłowej Człowieka,

Uniwersytet Medyczny w Lublinie,

ul. Jaczewskiego 4,

20-094 Lublin, Poland

e-mail: anna.torres@wp.pl

A. Torres

e-mail: anna.torres@umlub.pl 
endometrial cancer group versus control group ( $p=0.008)$. Down-regulation of Dicer significantly correlated with decreased expression of Drosha (coefficient value 0.75). Decreased expression of Drosha correlated with higher histological grade and was influenced by BMI. Lower Dicer expression was found in nulli- and uniparous females comparing to multiparous individuals ( $p=0.002$ ). Neither the FIGO stage nor the menstrual status had significant influence on the expression of studied genes. This study revealed for the first time that expression alterations of main regulators of microRNAs biogenesis are present in endometrial cancer tissue and could be potentially responsible for altered microRNAs profiles observed in this malignancy.

Keywords Endometrial cancer - Dicer - Drosha $\cdot$ MicroRNA

\section{Introduction}

Endometrial cancer is the fourth most common cancer in the female population. It was estimated that 43,470 endometrial carcinoma cases would be newly diagnosed in 2010 in the USA [1]. Estimated number of new endometrial cancer cases diagnosed in 2008 in Europe equals 82,530 [2]. Deregulation of various molecules and signaling pathways has been implicated in endometrial oncogenesis; however, its exact pathogenesis has not been completely elucidated [3]. Discovery of microRNAs has brought a new insight into the pathogenesis of many diseases including endometrial cancer [4]. MicroRNAs are non-coding, single stranded RNAs, consisting of 22 to 26 nucleotides, which regulate gene expression on the posttranscriptional level. Studies of the past few years have established microRNAs as important molecules in the pathogenesis of various solid tumors, suggesting their possible role and utilization in cancer screening, treatment, and prediction of outcome $[4,5]$. Deregulation of microRNAs expression was also observed in endometrial cancer samples as reported by few studies [6-8]. However, the reasons of microRNAs expression alterations observed in this tumor type have not been elucidated so far. Deterioration of microRNA biogenesis machinery has been implied as one possible mechanism among other suggested causes like DNA mutations, single nucleotide polymorphism or epigenetic changes [9-14].

Drosha and Dicer are two major components of microRNA biogenesis machinery. MicroRNAs are transcribed by polymerase II as stem-loop molecules consisting of hundreds to thousands of nucleotides called primicroRNAs which are sequentially cleaved, first by Drosha, which produces so-called pre-microRNAs, and then by Dicer [15]. Drosha belongs to the ribonuclease III superfamily of double-stranded RNA-specific endoribonu- cleases, and cleaves pri-microRNAs into approximately 70 nucleotides (nt) hairpin pre-microRNAs. Interaction with exportin-5 and Ran-GTP facilitates transport of pre- microRNAs to the cytoplasm. Within the cytoplasm premicroRNAs are further processed by a multidomain protein Dicer into short double-stranded molecules [15]. Apart from Dicer and Drosha, which are main regulators of microRNA biogenesis, the complicated microRNA machinery involves other proteins including DGCR8 and Ago2, and recently discovered co-regulators KSRP, hnRNP A1, $\mathrm{p} 53, \mathrm{p} 63, \mathrm{p} 73$, which are thought to be involved in the tissue specific microRNA processing or connected with particular cellular conditions [16-20].

Two Dicer protein isoforms were discovered by Potenza et al. in neuroblastoma cells, the long named Dicer1, which was also found in various other tissues and the short one, called t-Dicer [21]. In 2005, Irvin-Wilson and Chaudhuri reported transcription of Dicer from an alternative promoter as well as alternative splicing of the $5^{\prime}$-exons of Dicer transcript in breast cancer cell lines, and recently, Grelier at al. described 14 putative variants of human Dicer mRNA in breast cancer. The three variants were found to encode a full-length protein (variants $\mathrm{a}, \mathrm{b}$, and $\mathrm{c}$ ), whereas two shorter variants $d$ and e encoded proteins of 113 and $92.7 \mathrm{kDa}$, respectively [22-24].

Alterations of Dicer and Drosha expression levels have been found to accompany microRNA deregulations in various malignancies including breast and ovarian cancers $[25,26]$. An importance of an intact expression of microRNA biogenesis genes was demonstrated in Dicer depleted mouse models, in which global decrease in microRNAs levels was observed and was connected with severe anatomical and functional alterations. Dicer depleted or mutant mice presented with developmental abnormalities and increased lethality, as well as axonal degeneration [27, 28]. Loss of Dicer expression in mice uterus and oviducts resulted in dramatic anatomical and histological abnormalities [29-31].

The present study aimed to investigate Dicer and Drosha genes expression in endometrial cancer samples by quantitive real-time PCR using validated reference genes and to analyze impact of clinicopathological parameters on their expression.

\section{Material and methods}

\section{Patients}

Altogether, forty-four patients were included in the study. All patients were explained the study purpose and informed consent was obtained from each study participant. The Medical University of Lublin Ethical Committee has approved the study design (decision \# KE-0254/22/2009). 
Twenty-six patients diagnosed with endometroid endometrial cancer by endometrial biopsy performed prior to the operation were included in the study. All patients were scheduled for the primary surgical treatment. None of the patients underwent any neoadiuvant therapy prior to the operation. Upon obtaining the full pathology report, FIGO (the International Federation of Gynecology and Obstetrics) staging of the disease progression was performed for each patient. Control samples were obtained from 18 females operated due to benign gynecological diseases other than of endometrial origin. Clinicopathological characteristics of the patients were summarized in Table 1 .

Sample collection and storage

Endometrial cancer samples were collected from histopathology confirmed endometrial endometrioid carcinoma bulk tumors obtained from patients undergoing hysterectomy. Normal endometrial samples were collected from patients undergoing hysterectomy due to benign gynecological diseases other than of endometrial origin. All tissue samples were collected no more than $15 \mathrm{~min}$ after resection of the uterus and were immediately immersed in RNAlater ${ }^{\mathrm{TM}}$ solution and incubated in that solution for another $24 \mathrm{~h}$ in $4^{\circ} \mathrm{C}$ (Ambion, USA). All samples were stored in $-80^{\circ} \mathrm{C}$ until RNA isolation. The samples were examined microscopically to ensure tumor cellularity greater than $70 \%$.

Table 1 Clinicopathological characteristics of the patients

\begin{tabular}{lcc}
\hline Characteristic & Endometrial cancer & Normal endometrium \\
\hline Age $(\text { years })^{*}$ & 59.6 & 46.25 \\
BMI $\left(\mathrm{kg} / \mathrm{m}^{2}\right)^{* *}$ & 30.75 & 27.73 \\
Menopausal status $(n)$ & & \\
Premenopausal & 6 & 15 \\
Postmenopausal & 20 & 3 \\
Parity $(n)$ & & \\
Nulli- and uniparous & 10 & 7 \\
Multiparous & 16 & 11 \\
FIGO stage & & \\
1 A & 13 & N/A \\
1 B & 8 & N/A \\
$>1$ & 5 & N/A \\
Myometrial invasion & & \\
$<0.5$ & 14 & N/A \\
$>0.5$ & 12 & N/A \\
Grade & & \\
1 & 14 & N/A \\
2 & 11 & N/A \\
3 & 1 & N/A \\
${ }^{*} p<0.001 ;{ }^{* *} p=0.25$ & &
\end{tabular}

RNA isolation and quality control

Isolation of total RNA was performed with mirVana Isolation Kit (Ambion) according to the manufacture's protocol. Forty to eighty milligrams of tissue were processed per sample. In order to reduce the amount of the residual genomic DNA, treatment with DNAase I was performed using the Turbo DNA-free ${ }^{\mathrm{TM}}$ Kit (Ambion) according the manufacturer's protocol. Concentration and purity of RNA were assessed using BioPhotometer plus (Eppendorf, Germany) and a TrayCell (Hellma GmbH\&Co, Germany). Integrity of the RNA was evaluated by electrophoresis using Agilent RNA Nano kit and the Agilent Bioanalyzer (Agilent Technologies, USA). The RIN (RNA integrity number) values obtained for endometrial cancer and control samples ranged between 6.6 and 9.4. The total list of RNA samples, which includes the RIN values and 260/280 ratios of all samples, was presented in Online Resource 1.

\section{Reverse transcription and real-time PCR}

Either $2 \mu \mathrm{g}$ or $500 \mathrm{ng}$ of total RNA was reverse transcribed using hexamer random primers and a High Capacity cDNA Reverse Transcritpion Kit with RNase Inhibitor (Ambion, USA). Reverse transcription was performed in the final volume of $20 \mu \mathrm{L}$. cDNA samples were tenfold diluted before real-time PCR. Amplifications of Dicer and Drosha were performed utilizing specific TaqMan ${ }^{\circledR}$ probes and primers purchased from Applied Biosystems, USA (assays IDs Hs00229023_ml and Hs01095033_m1, respectively). Dicer isoform 1 is encoded by two transcript variants 1 and 2. Primers and probe for Dicer1 were chosen to amplify both 1 and 2 transcript variants. In brief, each $20 \mu \mathrm{L}$ reaction consisted of $10 \mu \mathrm{L}$ TaqMan ${ }^{\circledR}$ Gene Expression Master Mix, $1 \mu \mathrm{L}$ assay, $5 \mu \mathrm{L}$ nuclease-free water and $4 \mu \mathrm{L}$ cDNA.

Real-time PCR protocol consisted of pre-incubation in $95^{\circ} \mathrm{C}$ for $10 \mathrm{~min}$ and 45 quantification cycles, each consisting of denaturizing at $95^{\circ} \mathrm{C}$ for $15 \mathrm{~s}$ and annealing/ extension at $55^{\circ} \mathrm{C}$ for $1 \mathrm{~min}$.

Amplification of four candidate reference genes, $A C T B$ (assay ID Hs99999903_m1), eIF6 (assay ID Hs001 58272_m1), RLPO (assay ID Hs99999902_m1), and HPRT (part number 4326321E) was additionally performed in all forty-four samples using TaqMan ${ }^{\circledR}$ probes and primers (Applied Biosystems, USA). RT-minus, no template control and inter-plate calibrators were included in every run. All real-time PCR reactions were carried out in triplicates in a Rotor Gene thermal cycler (Corbett Research, Australia).

Efficiencies of primer/probe sets as well as a dynamic range of the assays were determined by performing standard 
qPCR with seven 4-fold dilution of the commercially available cDNA. Efficiencies for all assays were calculated using the equation $E=10^{(-1 / \text { slope })}$ and were between 0.9 and 0.98 (data for each assay was included in the Online Resource 2).

\section{Statistical analysis}

Data analysis was performed using GenEx 5.2.7 software (MultiD Analyses AB, Sweden). EIF6 and HPRT were chosen to normalize for RNA quality and cDNA input, basing on the Normfinder analysis of the expression of the four candidate reference genes [32]. Normalization with inter-plate calibrators was performed to validate for technical variations between the runs. Mean and confidence interval were utilized for descriptive statistics. Differences between the groups were tested with either a student $t$ test, analysis of variance (one-way ANOVA with the Bonferroni post hoc test) or Mann-Whitney tests depending on the Kologomorov-Smirnov $p$ value results. All tests used for statistical analysis were two-sided. Correlations between Dicer and Drosha expressions and clinicopathological characteristics were assessed with Pearson test. $P$ value of less than 0.05 was established to denote significance in all statistical analyses performed in the study.

\section{Results}

The mean age of patients in the endometrial cancer group was higher comparing to control group; however, no correlation was found between age and Dicer and Drosha mRNA expression levels. The cancer and control groups did not differ significantly regarding BMI $(p=0.25)$.

Prior to statistical analysis, raw qPCR data of Dicer and Drosha mRNA expression were normalized to two reference genes, eIF6 and HPRT. The genes were chosen from the four candidate genes. The variability for the best combination of genes calculated by Normfinder was 0.189 , which was also confirmed by GeNorm [32, 33].

Our study revealed that both Dicer and Drosha mRNA expressions were significantly down-regulated in endometrial cancer samples comparing to control group (Figs. 1 and 2). Expression of Dicer was down-regulated in cancer group comparing to control group by the factor of 1.54 ( $p=$ 0.009). Drosha mean expression value was 1.4 times lower in endometrial cancer group versus control group with the $p$ value of 0.008 . Additionally, the correlation between downregulation of Dicer and Drosha was found with Pearson correlation coefficient value of 0.75 (Fig. 3).

To evaluate the influence of the clinical stage on Dicer and Drosha expression, endometrial cancer samples were divided into two groups. One group comprised samples

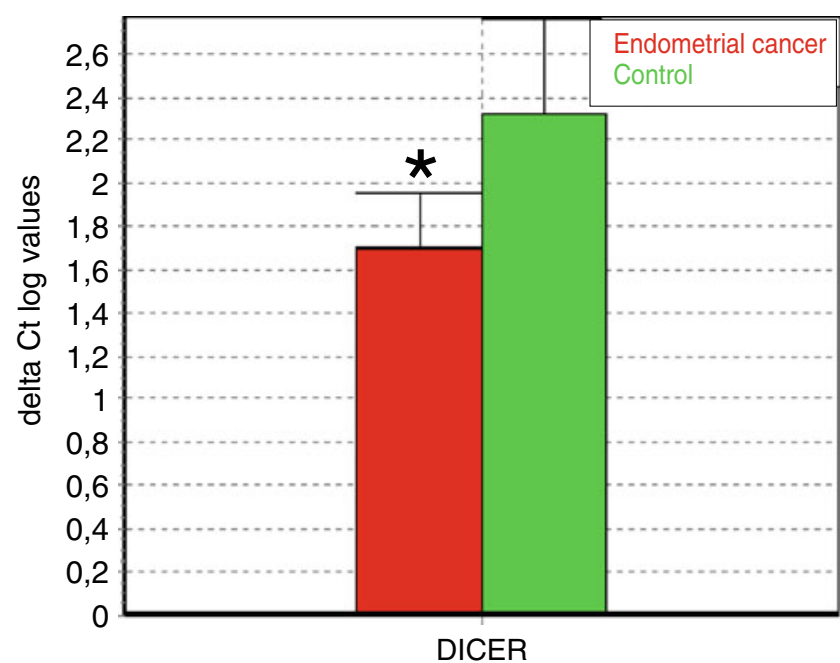

Fig. 1 Dicer expression in endometrial cancer samples and in the control group (values presented in the $\log$ scale); ${ }^{*} p=0.009$

staged as FIGO 1A and the other group consisted of allremaining samples, which were classified as FIGO stages 1B-3C. Statistical analysis did not reveal significant differences between two groups. Similarly, no significant differences were encountered when myometrial invasion was taken into account.

Analysis of variance (one-way ANOVA with the Bonferroni post hoc test) revealed the influence of histological grade on Drosha expression, with the significantly higher difference detected between controls and higher-grade cancers ( $p=$ 0.038 ). No influence of histological grade was detected in regards to expression of Dicer (Fig. 4).

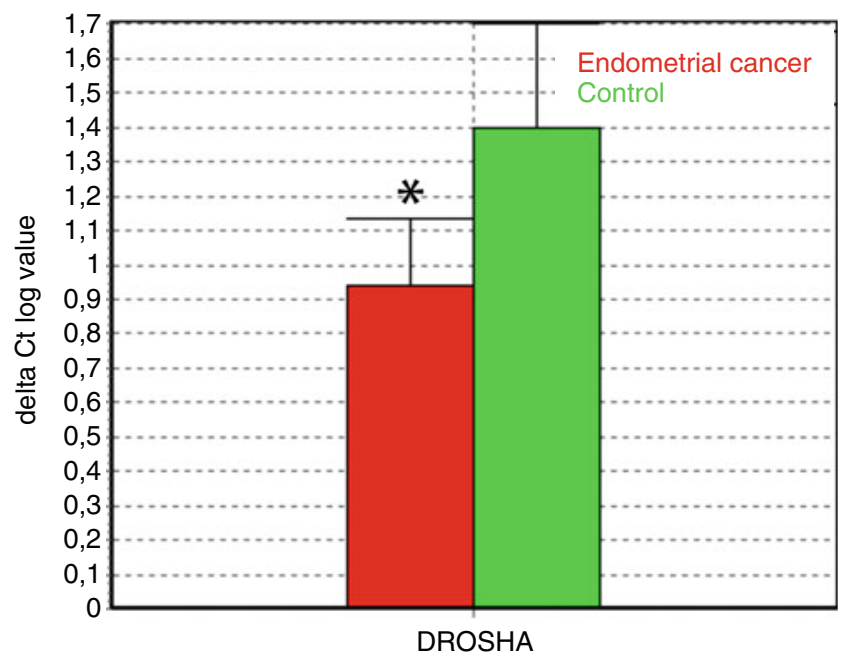

Fig. 2 Drosha expression in endometrial cancer samples and in the control group (values presented in the $\log$ scale); ${ }^{*} p=0.008$ 


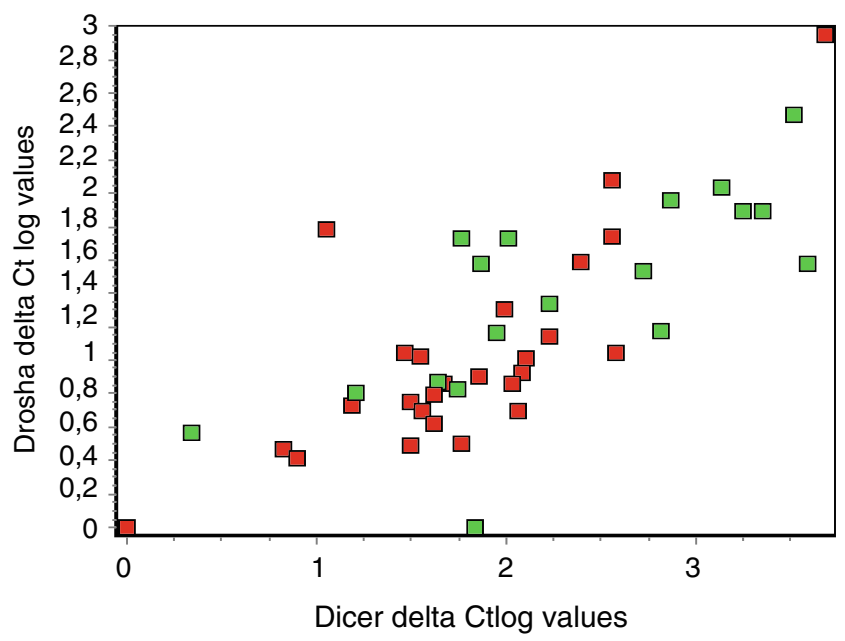

Fig. 3 Dicer and Drosha expression in endometrial cancer (red) and normal endometrial (green) samples

The influence of BMI on Dicer and Drosha expression was investigated separately in the endometrial cancer and control groups. The analysis of variance did not reveal any influence of BMI on Dicer gene expression in endometrial cancer group. The expression of Drosha, on the other hand, was influenced by BMI and the post hoc tests showed significant differences between normal weight $(\mathrm{BMI}<$ $\left.25 \mathrm{~kg} / \mathrm{m}^{2}, n=8\right)$ and overweight $\left(25 \mathrm{~kg} / \mathrm{m}^{2} \leq \mathrm{BMI}<30\right.$ $\left.\mathrm{kg} / \mathrm{m}^{2}, n=9\right)$ patients as well as between overweight and obese (BMI $\left.\geq 30 \mathrm{~kg} / \mathrm{m}^{2}, n=9\right)$ individuals $(p=0.003$ and $p=$ 0.02 , respectively). It is also worth to note that the

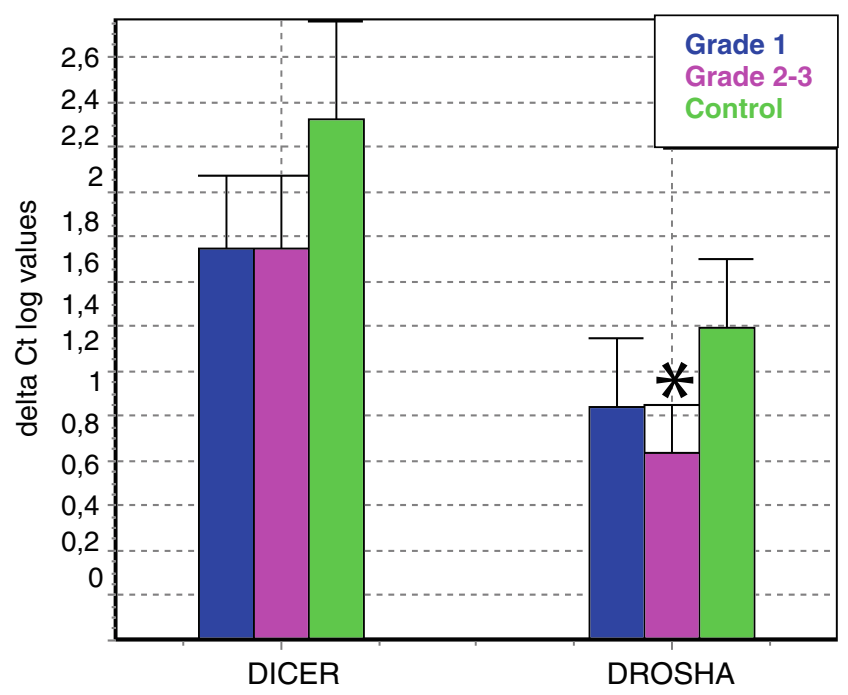

Fig. 4 The influence of histological grading on Dicer and Drosha expressions (values are presented in the log scale): one-way ANOVA with the Bonferroni post hoc test revealed the influence of histological grading on Drosha expression, with the significantly higher difference detected between controls and higher-grade cancers; ${ }^{*} p=0.038$ expression of both investigated genes was the lowest in the group consisting of overweight patients, although not significantly different in the case of Dicer. At the same time the number of high-grade tumors did not differ significantly between the three BMI groups. No influence of BMI on Dicer and Drosha mRNA levels was found in the control group.

Analysis of the influence of parity revealed significantly lower Dicer expression in cancerous samples collected from nulliparous and uniparous females comparing to those obtained from multiparous individuals $(p=0.002)$. No influence of parity was found in control samples.

A comparison of the data in regard to the menopausal status performed separately for cancer and control samples did not reveal any significant differences.

\section{Discussion}

Alterations of microRNAs expression profiles were reported in endometrial cancer by a number of studies; however, the underlying mechanism of the observed aberrations is still largely unresolved [6-8, 34-37]. Altered expression of the genes involved in the microRNA biogenesis has been implicated as a possible cause of the differences in the microRNA profiles between normal and cancerous tissues $[14,25,26]$. In addition, Dicer and Drosha expressions were investigated in regard to survival prediction in breast and ovarian cancers as well as in other malignancies [23, 38-44]. To the best of our knowledge, this is the first study to investigate Dicer and Drosha expressions in endometrial cancer. Using a quantitive realtime PCR approach and validated reference genes, we found a decreased expression of Dicer and Drosha transcripts in endometrial cancer samples in comparison to healthy controls. In addition, the down-regulation of Dicer significantly correlated with Drosha down-regulation. These results are in concordance with a number of studies, which investigated Dicer and/or Drosha gene expression levels in ovarian and breast cancers. Merritt et al. observed down-regulation of both Dicer and Drosha, and Pampalakis et al. observed down-regulation of Dicer in ovarian cancer samples [39, 45]. Moreover, in the study conducted by Merritt et al., low expression of Dicer comprised an independent predictor of the poor clinical outcome and reduced disease-specific survival. The same study revealed a correlation between Dicer and Drosha transcripts and protein expression [39]. In contrast, Flavin et al. observed increased Dicer mRNA and protein expression levels in ovarian cancer samples [46]. Several studies performed in breast cancer samples indicated down-regulation of Dicer and/or Drosha expression in malignant comparing to normal tissues [23, 38]. Most of those studies could not 
however demonstrate any concordance with the proteins expression [47, 48]. The results obtained by Grelier et al. suggested down-regulation of Dicer mRNA to be related with greater invasiveness and metastatic spread of breast carcinoma and to have an independent prognostic value in metastatic disease [23].

Higher histological grade was connected with greater invasiveness and worse prognosis in endometrial cancer $[49,50]$. Interestingly, our study revealed a correlation between higher-grade tumors and down-regulation of Drosha expression suggesting its possible connection with greater invasiveness and worse prognosis of endometrial cancer. Due to a short follow-up period, we could not however assess the prognostic value of Drosha in our sample group. The data revealed by our study warrants therefore further investigation with longer observation period and a larger group of patients.

The literature referring to the expression of Dicer and Drosha in other tumor types is inconsistent. Increased expression of Dicer mRNA and protein was found in prostate and esophageal carcinomas as well as in precursor lesions of lung adenocarcinoma, whereas decreased levels of both Dicer and Drosha were characteristic for high-risk neuroblastoma tumors. The down-regulation of Dicer mRNA was reported in hepatocellular carcinoma [41-43, 51, 52]. This may suggest tissue- and tumor-specific alterations in microRNA biogenesis genes.

Obesity comprises a well-known risk factor for endometrial cancer [53]. Therefore we analyzed the influence of BMI on Dicer and Drosha expression separately in cancer samples and in normal endometrium. We found that the expression of Drosha, but not Dicer, was influenced by BMI and the Bonferroni post hoc test revealed significant differences between the normal weight and overweight patients as well as between overweight and obese individuals. It is also worth to note that the expression levels of both investigated genes were the lowest in the group consisting of overweight patients, although not significantly different in the case of Dicer. As the histological grade influenced Drosha expression, we evaluated three BMI groups for the number of high-grade tumors and found no significant difference. In the study performed by Merritt et al., no significant associations were present between gene expression levels and age and tumor grade; however, low Dicer mRNA level was correlated with advanced tumor stage [39]. Other investigators demonstrated similar associations in ovarian and breast carcinomas $[23,38,45]$. In our study, there was no significant association between down-regulation of Dicer and Drosha and more advanced tumor stages; however, there was a trend toward lower expression levels in FIGO stages higher than $1 \mathrm{~A}$.
The reasons for alterations in Dicer and Drosha expression observed in our study and other reports published to date are largely unknown. One possible hypothesis might be connected with the Dicer gene location at the subtelomeric region on the chromosome 14 (14q32.13), which was found affected by allelic deletion in various tumors $[54,55]$. Interestingly, Fujino et al. reported a high percentage of endometrial cancers presenting loss of heterozygosity (LOH) on $14 \mathrm{q}$ chromosome and defined a minimal region of deletion for these tumors to region $14 \mathrm{q} 32$. In addition, investigators observed a strong association between 14q LOH and poor clinical outcome [56].

Biocomputational analysis performed by Pampalakis et al. indicated DNA methylation as a possible mechanism of Dicer down-regulation based on the presence of the strong CpG island spanning the first exon of the gene $[45,50]$. Although methylation of Dicer gene was not detected in a lung adenocarcinoma, this possibility warrants further investigation [40].

Recent studies suggested that regulation of Dicer expression could appear at the posttranscriptional level involving both mRNA and protein stage $[57,58]$. In silico algorithms revealed Dicer mRNA to bear several binding sides for a number of various microRNAs. It was also suggested that target sites located within the coding region, which were recently found for let-7, could differ in mechanism of posttranscriptional repression. Thus, microRNAs by targeting various sites could potentially lead not only to translational inhibition but also cause mRNA instability [57, 58].

Interestingly, our search performed with DianamicroT 3.0 and TargetScan revealed that a number of microRNAs previously reported to be up-regulated in endometrial cancer targeted Dicer mRNA [59, 60]. As an example, Boren et al. reported a significant up-regulation of miR-103, miR-107, and let-7c, which are strongly associated with $3^{\prime} \mathrm{UTR}$ region of Dicer mRNA [35]. Additionally, miR-200a and miR-141 as well as miR-9, predicted by TargetSan, were up-regulated in the microarray study performed by our team (data not published, article under review).

Deregulation of $\mathrm{p} 53$ protein has been well established in the pathogenesis of endometrial cancer. P53 alterations have been mostly connected to the non-endometrioid adenocarcinoma. Still, mutations in p53 gene were reported in $4-32 \%$ of endometroid endometrial cancers and were recently proposed as prognostic factors [61, 62]. P63 and p73 protein alterations were also observed in endometrioid endometrial tumors [61, 62]. At the same time, recent studies suggested involvement of the p53, p63, and p73 in regulation of microRNA processing components including Dicer and Drosha. According to that hypothesis Dicer and Drosha could be regulated either at the transcription step or 
indirectly by $\mathrm{p} 53 / \mathrm{p} 63 / \mathrm{p} 73$-dependent microRNAs at the posttranscriptional level [63].

In summary, our study revealed for the first time that expression alterations of main regulators of microRNAs biogenesis are present in endometrial cancer tissue and could be potentially responsible for altered microRNAs profiles observed in this malignancy. This interesting observation warrants further studies, which would explore correlations with protein expression as well as functional sequel and consequences of Dicer and Drosha expression deregulation in endometrial cancer cell lines.

Conflict of interest The authors declare that they have no conflict of interest.

Role of the funding source The study was supported by the Medical University of Lublin (DS 201, PW 203) and Polish Ministry of Science and Higher Education grant \# NN407570538. The funding sources had no involvement in study design, collection, analysis, and interpretation of data, in the writing of the report and in the decision to submit the paper for publication.

Open Access This article is distributed under the terms of the Creative Commons Attribution Noncommercial License which permits any noncommercial use, distribution, and reproduction in any medium, provided the original author(s) and source are credited.

\section{References}

1. Jemal A, Siegel R, Xu J, Ward E. Cancer statistics, 2010. CA Cancer J Clin. 2010;60:277-300.

2. Ferlay J, Parkin DM, Steliarova-Foucher E. Estimates of cancer incidence and mortality in Europe in 2008. Eur J Cancer. 2010;46:765-81.

3. Prat J, Gallardo A, Cuatrecasas M, Catasús L. Endometrial carcinoma: pathology and genetics. Pathology. 2007;39:72-87.

4. Kwak PB, Iwasaki S, Tomari Y. The microRNA pathway and cancer. Cancer Sci. 2010;101:2309-15.

5. Kosaka N, Iguchi H, Ochiya T. Circulating microRNA in body fluid: a new potential biomarker for cancer diagnosis and prognosis. Cancer Sci. 2010;101:2087-92.

6. Ratner ES, Tuck D, Richter C, Nallur S, Patel RM, Schultz V, et al. MicroRNA signatures differentiate uterine cancer tumor subtypes. Gynecol Oncol. 2010;118:251-7.

7. Cohn DE, Fabbri M, Valeri N, Alder H, Ivanov I, Liu CG, et al. Comprehensive miRNA profiling of surgically staged endometrial cancer. Am J Obstet Gynecol. 2010;202:656e1-8.

8. Wu W, Lin Z, Zhuang Z, Liang X. Expression profile of mammalian microRNAs in endometrioid adenocarcinoma. Eur $\mathbf{J}$ Cancer Prev. 2009;18:50-5.

9. Sun Q, Gu H, Zeng Y, Xia Y, Wang Y, Jing Y, et al. Hsa-mir-27a genetic variant contributes to gastric cancer susceptibility through affecting miR-27a and target gene expression. Cancer Sci. 2010;101:2241-7.

10. Christensen BC, Avissar-Whiting M, Ouellet LG, Butler RA, Nelson HH, McClean MD, et al. Mature microRNA sequence polymorphism in MIR196A2 is associated with risk and prognosis of head and neck cancer. Clin Cancer Res. 2010;16:3713-20.

11. Dudziec E, Miah S, Choudhry H, Owen HC, Blizard S, Glover M, et al. Hypermethylation of $\mathrm{CpG}$ Islands and Shores around specific MicroRNAs and Mirtrons is associated with the phenotype and presence of Bladder Cancer. Clin Cancer Res. 2010. doi:10.1158/1078-0432.CCR-10-2017.

12. de Souza Rocha Simonini P, Breiling A, Gupta N, Malekpour M, Youns M, Omranipour R, et al. Epigenetically deregulated microRNA-375 is involved in a positive feedback loop with estrogen receptor alpha in breast cancer cells. Cancer Res. 2010;70:9175-84.

13. Grosshans H, Büssing I. MicroRNA biogenesis takes another single hit from microsatellite instability. Cancer Cell. 2010;18:295-7.

14. Han L, Zhang A, Zhou X, Xu P, Wang GX, Pu PY, et al. Downregulation of Dicer enhances tumor cell proliferation and invasion. Int J Oncol. 2010;37:299-305.

15. Schmittgen TD. Regulation of microRNA processing in development, differentiation and cancer. J Cell Mol Med. 2008;12:1811-9.

16. Guil S, Cáceres JF. The multifunctional RNA-binding protein hnRNP A1 is required for processing of miR-18a. Nat Struct Mol Biol. 2007;14:591-6.

17. Davis BN, Hilyard AC, Nguyen PH, Lagna G, Hata A. Smad proteins bind a conserved RNA sequence to promote microRNA maturation by Drosha. Mol Cell. 2010;39:373-84.

18. Trabucchi M, Briata $P$, Garcia-Mayoral $M$, Haase AD, Filipowicz W, Ramos A, et al. The RNA-binding protein KSRP promotes the biogenesis of a subset of microRNAs. Nature. 2009;459:1010-4.

19. Suzuki HI, Yamagata K, Sugimoto K, Iwamoto T, Kato S, Miyazono K. Modulation of microRNA processing by $\mathrm{p} 53$. Nature. 2009;460:529-33.

20. Su X, Chakravarti D, Cho MS, Liu L, Gi YJ, Lin YL, et al. TAp63 suppresses metastasis through coordinate regulation of Dicer and miRNAs. Nature. 2010;467:986-90.

21. Potenza N, Papa U, Scaruffi P, Mosca N, Tonini GP, Russo A. A novel splice variant of the human dicer gene is expressed in neuroblastoma cells. FEBS Lett. 2010;584:3452-7.

22. Irvin-Wilson CV, Chaudhuri G. Alternative initiation and splicing in dicer gene expression in human breast cells. Breast Cancer Res. 2005; 7:R563-9.

23. Grelier G, Voirin N, Ay AS, Cox DG, Chabaud S, Treilleux I, et al. Prognostic value of Dicer expression in human breast cancers and association with the mesenchymal phenotype. Br J Cancer. 2009;101:673-83.

24. Hinkal GW, Grelier G, Puisieux A, Moyret-Lalle C. Complexity in the regulation of Dicer expression: Dicer variant proteins are differentially expressed in epithelial and mesenchymal breast cancer cells and decreased during EMT. Br J Cancer. 2011;104:387-8.

25. Faggad A, Budczies J, Tchernitsa O, Darb-Esfahani S, Sehouli J, Müller BM, et al. Prognostic significance of Dicer expression in ovarian cancer-link to global microRNA changes and oestrogen receptor expression. J Pathol. 2010;220:382-91.

26. Cheng $\mathrm{C}, \mathrm{Fu} \mathrm{X}$, Alves $\mathrm{P}$, Gerstein $\mathrm{M}$. mRNA expression profiles show differential regulatory effects of microRNAs between estrogen receptor-positive and estrogen receptor-negative breast cancer. Genome Biol. 2009;10:R90.

27. Bernstein E, Kim SY, Carmell MA, Murchison EP, Alcorn H, Li $\mathrm{MZ}$, et al. Dicer is essential for mouse development. Nat Genet. 2003;35:215-7.

28. Pereira JA, Baumann R, Norrmén C, Somandin C, Miehe M, Jacob C, et al. Dicer in Schwann cells is required for myelination and axonal integrity. J Neurosci. 2010;30:6763-75. 
29. Hong X, Luense LJ, McGinnis LK, Nothnick WB, Christenson LK. Dicer1 is essential for female fertility and normal development of the female reproductive system. Endocrinology. 2008;149:6207-12.

30. Nagaraja AK, Andreu-Vieyra C, Franco HL, Ma L, Chen R, Han DY, et al. Deletion of Dicer in somatic cells of the female reproductive tract causes sterility. Mol Endocrinol. 2008;22:2336-52.

31. Gonzalez G, Behringer RR. Dicer is required for female reproductive tract development and fertility in the mouse. Mol Reprod Dev. 2009;76:678-88.

32. Andersen CL, Jensen JL, Ørntoft TF. Normalization of real-time quantitative reverse transcription-PCR data: a model-based variance estimation approach to identify genes suited for normalization, applied to bladder and colon cancer data sets. Cancer Res. 2004;64:5245-50.

33. Vandesompele J, De Preter K, Pattyn F, Poppe B, Van Roy N, De Paepe A, et al. Accurate normalization of real-time quantitative RT-PCR data by geometric averaging of multiple internal control genes. Genome Biol. 2002;3:reasearch0034-reasearch0034.11. doi:10.1186/gb-2002-3-7-research0034.

34. Lee JW, Park YA, Choi JJ, Lee YY, Kim CJ, Choi C, et al. The expression of the miRNA-200 family in endometrial endometrioid carcinoma. Gynecol Oncol. 2011;120:56-62.

35. Myatt SS, Wsb ang J, Monteiro LJ, Christian M, Ho KK, Fusi L, et al. Definition of microRNAs that repress expression of the tumor suppressor gene FOXO1 in endometrial cancer. Cancer Res. 2010;70:367-77.

36. Boren T, Xiong Y, Hakam A, Wenham R, Apte S, Wei Z, et al. MicroRNAs and their target messenger RNAs associated with endometrial carcinogenesis. Gynecol Oncol. 2008;110:20615.

37. Chung TK, Cheung TH, Huen NY, Wong KW, Lo KW, Yim SF, et al. Dysregulated microRNAs and their predicted targets associated with endometrioid endometrial adenocarcinoma in Hong Kong women. Int J Cancer. 2009;124:1358-65.

38. Dedes KJ, Natrajan R, Lambros MB, Geyer FC, Lopez-Garcia MA, Savage K, et al. Down-regulation of the miRNA master regulators Drosha and Dicer is associated with specific subgroups of breast cancer. Eur J Cancer. 2011;47:138-50

39. Merritt WM, Lin YG, Han LY, Kamat AA, Spannuth WA, Schmandt R, et al. Dicer, Drosha, and outcomes in patients with ovarian cancer. N Engl J Med. 2008;359:2641-50.

40. Karube Y, Tanaka H, Osada H, Tomida S, Tatematsu Y, Yanagisawa $\mathrm{K}$, et al. Reduced expression of Dicer associated with poor prognosis in lung cancer patients. Cancer Sci. 2005;96:111-5.

41. Chiosea S, Jelezcova E, Chandran U, Acquafondata M, McHale T, Sobol RW, et al. Up-regulation of dicer, a component of the MicroRNA machinery, in prostate adenocarcinoma. Am J Pathol. 2006;169:1812-20.

42. Sugito N, Ishiguro H, Kuwabara Y, Kimura M, Mitsui A, Kurehara $\mathrm{H}$, et al. RNASEN regulates cell proliferation and affects survival in esophageal cancer patients. Clin Cancer Res. 2006;12:7322-8.

43. Lin RJ, Lin YC, Chen J, Kuo HH, Chen YY, Diccianni MB, et al. microRNA signature and expression of Dicer and Drosha can predict prognosis and delineate risk groups in neuroblastoma. Cancer Res. 2010;70:7841-50.

44. Lin J, Horikawa Y, Tamboli P, Clague J, Wood CG, Wu X. Genetic variations in microRNA-related genes are associated with survival and recurrence in patients with renal cell carcinoma. Carcinogenesis. 2010;31:1805-12.

45. Pampalakis G, Diamandis EP, Katsaros D, Sotiropoulou G. Downregulation of dicer expression in ovarian cancer tissues. Clin Biochem. 2010;43:324-7.
46. Flavin RJ, Smyth PC, Finn SP, Laios A, O'Toole SA, Barrett C, et al. Altered eIF6 and Dicer expression is associated with clinicopathological features in ovarian serous carcinoma patients. Mod Pathol. 2008;21:676-84.

47. Wiesen JL, Tomasi TB. Dicer is regulated by cellular stresses and interferons. Mol Immunol. 2009;46:1222-8.

48. Blenkiron C, Goldstein LD, Thorne NP, Spiteri I, Chin SF, Dunning MJ, et al. MicroRNA expression profiling of human breast cancer identifies new markers of tumor subtype. Genome Biol. 2007;8:R214.

49. Celik C, Ozdemir S, Esen H, Balci O, Ylmaz O. The clinical value of preoperative and intraoperative assessments in the management of endometrial cancer. Int J Gynecol Cancer. 2010;20:358-62.

50. Bassarak N, Blankenstein T, Brüning A, Dian D, Bergauer F, Friese $\mathrm{K}$, et al. Is lymphadenectomy a prognostic marker in endometrioid adenocarcinoma of the human endometrium? BMC Cancer. 2010;10:224.

51. Chiosea S, Jelezcova E, Chandran U, Luo J, Mantha G, Sobol $\mathrm{RW}$, et al. Overexpression of Dicer in precursor lesions of lung adenocarcinoma. Cancer Res. 2007;67:2345-50.

52. Wu JF, Shen W, Liu NZ, Zeng GL, Yang M, Zuo GQ, et al. Down-regulation of Dicer in hepatocellular carcinoma. Med Oncol. 2010. doi:10.1007/s12032-010-9520-5.

53. Haidopoulos D, Simou M, Akrivos N, Rodolakis A, Vlachos G, Fotiou S, et al. Risk factors in women 40 years of age and younger with endometrial carcinoma. Acta Obstet Gynecol Scand. 2010;89:1326-30.

54. Matsuda S, Ichigotani $\mathrm{Y}$, Okuda $\mathrm{T}$, Irimura $\mathrm{T}$, Nakatsugawa $\mathrm{S}$, Hamaguchi M. Molecular cloning and characterization of a novel human gene (HERNA) which encodes a putative RNA-helicase. Biochim Biophys Acta. 2000;1490:163-9.

55. Kagami M, Sekita Y, Nishimura G, Irie M, Kato F, Okada M, et al. Deletions and epimutations affecting the human $14 \mathrm{q} 32.2$ imprinted region in individuals with paternal and maternal upd (14)-like phenotypes. Nat Genet. 2008;40:237-42.

56. Fujino T, Risinger JI, Collins NK, Liu FS, Nishii H, Takahashi H, et al. Allelotype of endometrial carcinoma. Cancer Res. 1994;54:4294-8.

57. Tokumaru S, Suzuki M, Yamada H, Nagino M, Takahashi T. let-7 regulates Dicer expression and constitutes a negative feedback loop. Carcinogenesis. 2008;29:2073-7.

58. Forman JJ, Legesse-Miller A, Coller HA. A search for conserved sequences in coding regions reveals that the let-7 microRNA targets Dicer within its coding sequence. Proc Natl Acad Sci USA. 2008;105:14879-84.

59. Maragkakis M, Reczko M, Simossis VA, Alexiou P, Papadopoulos GL, Dalamagas T, et al. DIANA-microT web server: elucidating microRNA functions through target prediction. Nucleic Acids Research. 2009;37(2):W273-6.

60. Grimson A, Farh KK, Johnston WK, Garrett-Engele P, Lim LP, Bartel DP. MicroRNA targeting specificity in mammals: determinants beyond seed pairing. Mol Cell. 2007;27:91-105.

61. Steinbakk A, Skaland I, Gudlaugsson E, Janssen EA, Kjellevold KH, Klos J, et al. The prognostic value of molecular biomarkers in tissue removed by curettage from FIGO stage 1 and 2 endometrioid type endometrial cancer. Am J Obstet Gynecol. 2009;200:78.e1-8.

62. Niwa Y, Hirose K, Matsuo K, Tajima K, Ikoma Y, Nakanishi T, et al. Association of p73 G4C14-to-A4T14 polymorphism at exon 2 and p53 Arg72Pro polymorphism with the risk of endometrial cancer in Japanese subjects. Cancer Lett. 2005;219:183-90.

63. Boominathan L. The tumor suppressors $\mathrm{p} 53$, p63, and $\mathrm{p} 73$ are regulators of microRNA processing complex. PLoS ONE. 2010;5: e10615. 